\title{
ORGANIC MATTER FRACTIONS OF AN IRRIGATED OXISOL UNDER NO-TILL AND CONVENTIONAL TILLAGE IN THE BRAZILIAN SEMI-ARID REGION $^{1}$
}

\author{
RAFAEL PEREIRA SALES ${ }^{2}$, RODINEI FACCO PEGORARO ${ }^{3}$, ARLEY FIGUEIREDO PORTUGAL $^{4}$, JOSÉ ALOÍSIO \\ ALVES MOREIRA ${ }^{4}$, MARCOS KOITI KONDO ${ }^{2}$
}

\begin{abstract}
The replacement of natural vegetation by crop systems directly impacts the soil organic matter fractions. The objective of this study was to evaluate the total organic carbon (TOC) and nitrogen (TN) contents in different fractions of the soil organic matter (SOM) of an Oxisol of the Brazilian semiarid region under different irrigated crops and different soil management systems. Seven treatments were evaluated, which consisted of two soil management systems (no-till and conventional tillage) and three crops (maize, sunflower and sorghum), using as reference the soil under a native forest (NF). The summer crops preceded common bean crops in the autumn-winter. The total organic carbon content, total nitrogen, carbon content in humic substances and their constituents (fulvic acids, humic acids and humin) and labile, non-labile and water-soluble carbon contents were evaluated two years and three months after the experiment implementation to determine the carbon lability (L) lability index (LI), partitioning index (CPI) and management index (CMI). The greatest carbon, nitrogen and organic matter contents in the soil surface layer (0.00-0.05 m) were found in crops under no-till system (NTS), especially maize. The crops under NTS presented greater carbon content in humic substances than the conventional tillage system (CTS) ones in the layer 0.05-0.10 m. The crops under NTS presented greater sustainability in the Brazilian semiarid region compared with those under CTS, as shown by their higher CMI in the soil surface layer.
\end{abstract}

Keywords: Humic substances. Labile carbon. Sustainability.

\section{FRAÇÕES DA MATÉRIA ORGÂNICA EM LATOSSOLO IRRIGADO NO SEMIÁRIDO SOB PLANTIO DIRETO E PREPARO CONVENCIONAL}

\begin{abstract}
RESUMO - A substituição da vegetação natural pela agricultura impacta diretamente as frações da matéria orgânica no solo. Este estudo avaliou os teores de carbono orgânico total (COT) e nitrogênio total (NT) nas frações da matéria orgânica do solo (MOS) em um Latossolo do semiárido brasileiro sob diferentes sistemas de manejo com diferentes culturas irrigadas. Os sete tratamentos foram compostos por dois sistemas de manejo do solo (plantio direto e convencional) e três culturas: sorgo, girassol e milho tendo como referência o solo sob mata nativa $(\mathrm{MN})$. A semeadura das culturas no verão precedeu a semeadura de feijão no outono/inverno. Após dois anos e três meses de implantação, avaliaram-se os teores de carbono orgânico total, nitrogênio total, teor de carbono nas substâncias húmicas e seus constituintes (fração ácidos fúlvicos, húmicos e humina), teores de carbono lábil, carbono não-lábil e carbono solúvel em água, sendo determinados a labilidade (L), índice de labilidade (IL), índice de compartimento de carbono (ICC) e índice de manejo de carbono (IMC). Os cultivos sob sistema de plantio direto (SPD) nas condições semiáridas, em especial com o milho, promoveram maiores teores de carbono, nitrogênio e frações da matéria orgânica, na camada superficial do solo $(0,00$ a $0,05 \mathrm{~m})$. Na camada de 0,05-0,10 m os cultivos sob SPD promoveram aumento nos teores de carbono nas substâncias húmicas, em comparação aos SPC. Maior sustentabilidade foi observada nos cultivos em SPD no semiárido, em relação àqueles sob SPC, indicado pelos maiores IMC na camada superficial do solo sob SPD.
\end{abstract}

Palavras-chave: Substâncias húmicas. Carbono lábil. Sustentabilidade.

\footnotetext{
*Corresponding author

${ }^{1}$ Received for publication in 11/04/2014; accepted in 10/10/2016.

Paper extracted from the master dissertation of the first author.

${ }^{2}$ Postgraduate Program in Semi-Arid Crop Production, Universidade Estadual de Montes Claros, Janaúba, MG, Brazil; rafaelpereirasales@gmail.com, marcos.kondo@unimontes.br.

${ }^{3}$ Institute of Agricultural Sciences, Universidade Federal de Minas Gerais, Montes Claros, MG, Brazil; rodinei_pegoraro@yahoo.com.br.

${ }^{4}$ Embrapa Milho e Sorgo, Sete Lagoas, MG, Brazil; arley.portugal@embrapa.br, jose.aloisio@embrapa.br.
} 


\section{INTRODUCTION}

Assessments on changes in the amount of carbon $(\mathrm{C})$ in the fractions of the soil organic matter (SOM) allows to evaluate the possible impacts of soil management in agricultural systems (SILVA et al., 2011). The labile SOM fraction is ephemeral, with a high rate of decomposition, releasing nutrients to plants by mineralization, as well as energy and C to soil organisms. This fraction consists mainly of water-soluble carbon (WSC) and labile carbon (LC), which are very sensitive to changes in land use (SCHIAVO et al., 2011).

The humified fraction is a more stable partition of the SOM, which consists mainly of humic substances (HS), representing 85 to $90 \%$ of the total organic carbon (TOC). HS are the most recalcitrant, stabilized and chemically reactive SOM fraction, which affect various properties that determine the quality of tropical soils that are highly weathered and poor in available nutrients to plants (SILVA; MENDONÇA, 2007). Thus, humic substances are the most assessed soil partition in studies evaluating the impacts of soil management systems on the SOM (ROSSI et al., 2012; CAMPOS et al., 2013; GUARESCHI; PEREIRA; PERIN, 2013).

The replacement of native vegetation by crop systems changes the soil quality, reducing TOC contents, reaching soil $\mathrm{C}$ losses of $0.60(0.00-0.20 \mathrm{~m})$ and $1.07(0.20-0.40 \mathrm{~m}) \mathrm{Mg} \mathrm{ha}^{-1} \mathrm{yr}^{-1}$ in conventional tillage system (CTS), and affects the organic matter fractions, and the soil physical, chemical and biological properties, especially in the surface layers (SÁ et al., 2014). The cultivated soils of the Brazilian semiarid region remain exposed for long periods of drought without recovering its natural vegetation cover, reducing its productive potential and increasing degradation (MARINHO et al., 2016).

The CTS causes the greatest land use impacts by disturbing the topsoil, causing soil disaggregation, increasing the SOM decomposition, reducing the soil carbon and nitrogen contents and hindering the soil chemical and physical properties (SCHIMIGUEL et al., 2014). On the other hand, the no-till system (NTS) has increasing the TOC and humic substances of the soil by using soil tillage only in the plant row and maintenance of vegetation cover (CAMPOS et al., 2013; DORADO; ALMENDROS; GONZÁLEZ-VILA, 2016). The use of grasses in
NTS increases the straw production and thus, the soil carbon and nitrogen contents, especially in crops intercropped with legumes (ALVAREZ et al., 2014).

The content of labile carbon in the SOM and the carbon management index (CMI) proposed by Blair, Lefroy and Lisle (1995), allows to evaluate the impacts of soil management systems on the SOM qualitative and quantitative characteristics, since the CMI is a widely-used indicator of sustainability (ROSSI et al., 2012) and carbon management (CAMPOS et al., 2013; LEITE et al., 2013). More sustainable soil management systems, such as the NTS, increase the CMI to near 100, while soil management systems that cause negative impacts to the soil, such as the CTS, decrease the CMI (CAMPOS et al., 2013; CONCEIÇÃO et al., 2014).

In the high temperatures and solar radiation and low rainfall of the Brazilian semiarid region, the use of soil management systems that result in low amounts of plant residues left on the soil surface and continuous soil tillage reduce the TOC (SACRAMENTO et al., 2013), decreasing the soil quality and productive capacity, especially in the topsoil of intensive irrigated crops (ASSIS et al., 2010).

The objective of this study was to evaluate the total organic carbon (TOC) and nitrogen (TN) contents in different fractions of soil organic matter (SOM) in an Oxisol of the Brazilian semiarid region, and the carbon management index (CMI) of different irrigated crops under different soil management systems.

\section{MATERIAL AND METHODS}

The experiment was conducted in an experimental area in Nova Porteirinha, Minas Gerais $\left(15^{\circ} 45^{\prime} 01^{\prime \prime S}, 43^{\circ} 17^{\prime} 29^{\prime \prime} \mathrm{W}\right.$ and altitude of $\left.524.0 \mathrm{~m}\right)$. The monthly averages of rainfall and temperature of the experimental period (November 2009 to February 2012) are shown in Figure 1. According to the Köppen classification, the region has a savannah climate (Aw), with dry winter and average air temperature in the coldest month exceeding $18^{\circ} \mathrm{C}$. The predominant soil of the region was classified as Oxisol (eutrophic Red-Yellow Latosol - SiBCS) of medium texture (RESENDE; FERNANDES; COELHO, 1969), and the predominant vegetation as Deciduous Forest, also known as "mata seca". 


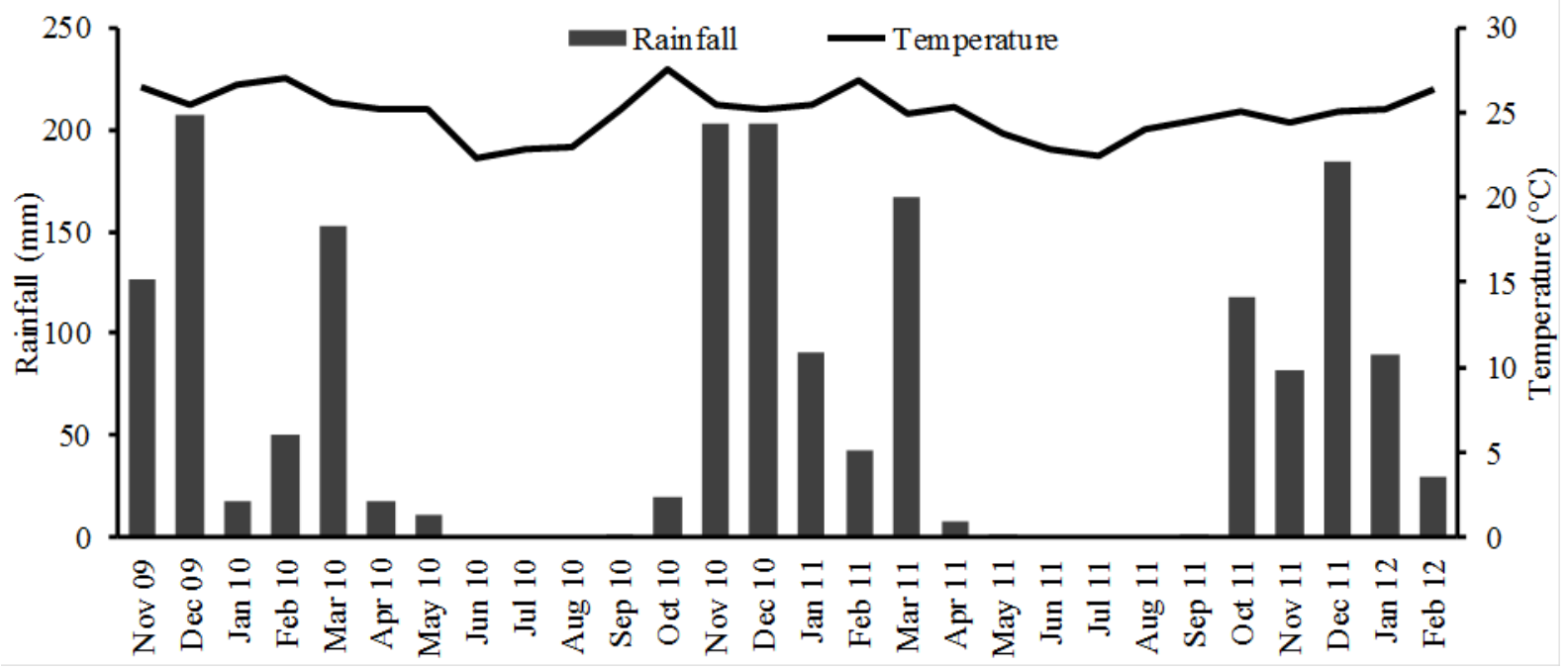

Figure 1. Monthly averages of rainfall and temperature of the period from the experiment implementation to the treatment evaluations.

A particle size analysis was carried out by the pipette method (DONAGEMA, 2011), which showed the mean contents of coarse sand (2-0.2 mm) $\left(120 \mathrm{~g} \mathrm{~kg}^{-1}\right)$, fine sand $(0.2-0.053 \mathrm{~mm})\left(370 \mathrm{~g} \mathrm{~kg}^{-1}\right)$, silt $\left(210 \mathrm{~g} \mathrm{~kg}^{-1}\right)$ and clay $\left(300 \mathrm{~g} \mathrm{~kg}^{-1}\right)$ in the soil layer $0.00-0.20 \mathrm{~m}$, and coarse sand $\left(118 \mathrm{~g} \mathrm{~kg}^{-1}\right)$, fine sand $\left(372 \mathrm{~g} \mathrm{~kg}^{-1}\right)$, silt $\left(215 \mathrm{~g} \mathrm{~kg}^{-1}\right)$ and clay $\left(295 \mathrm{~g} \mathrm{~kg}^{-1}\right)$ in the soil layer $0.20-0.40 \mathrm{~m}$. The soil was classified as medium texture, equivalent to sandy-clay-loam (SANTOS et al, 2013). The results of the chemical analysis of the soil layers $0.00-0.20$ and $0.20-0.40 \mathrm{~m}$ of the study area assessed before the experiment implementation are shown in Table 1.

Table 1. Chemical attributes of the layers $0.00-0.20$ (a) and $0.20-0.40 \mathrm{~m}$ (b) of the Oxisol (medium-texture eutrophic Red-Yellow Latosol - SiBCS) before the experiment implementation.

\begin{tabular}{|c|c|c|c|c|c|c|c|c|c|c|c|c|c|c|c|c|c|}
\hline & ${ }^{1} \mathrm{pH}$ & ${ }^{2} \mathrm{OM}$ & ${ }^{3} \mathrm{P}$ & ${ }^{3} \mathrm{~K}$ & ${ }^{4} \mathrm{Ca}$ & ${ }^{4} \mathrm{Mg}$ & ${ }^{4} \mathrm{Al}$ & ${ }^{5} \mathrm{H}+\mathrm{Al}$ & SB & eCEC & CEC & BS & AlS & ${ }^{3} \mathrm{Cu}$ & ${ }^{3} \mathrm{Fe}$ & ${ }^{3} \mathrm{Mn}$ & ${ }^{3} \mathrm{Zn}$ \\
\hline & & dag $\mathrm{kg}^{-1}$ & $-\mathrm{mg}$ & $\mathrm{dm}^{-3}-$ & & & & $-\mathrm{cmol}_{\mathrm{c}} \mathrm{d}$ & & & - & $-\%$ & 6 - & & $-\mathrm{mg}$ & $m^{-3}$ & \\
\hline (a) & 6.0 & 1.6 & 34.2 & 265.6 & 4.0 & 1.0 & 0.0 & 1.6 & 5.6 & 5.6 & 7.3 & 77.6 & 0.0 & 0.8 & 13.8 & 17.0 & 5.3 \\
\hline (b) & 6.1 & 0.7 & 5.0 & 147.9 & 3.1 & 1.3 & 0.2 & 1.7 & 4.8 & 5.0 & 6.5 & 73.8 & 4.2 & 0.9 & 10.2 & 6.2 & 0.7 \\
\hline
\end{tabular}

${ }^{1} \mathrm{pH}$ in $\mathrm{H}_{2} \mathrm{O}$ (DONAGEMA, 2011); ${ }^{2} \mathrm{OM}$ : organic matter determined by wet oxidation (YEOMANS; BREMNER, 1988); ${ }^{3}$ Extracted in the Mehlich-1 solution; ${ }^{4}$ Extracted in the $\mathrm{KCl} 1 \mathrm{~mol} \mathrm{~L}^{-1} ;{ }^{5} \mathrm{pH}$ SMP; SB: sum of bases; eCEC: effective cation exchange capacity; $\mathrm{CEC}$ : buffered $(\mathrm{pH}=7)$ cation exchange capacity; $\mathrm{BS}$ : base saturation; AlS: aluminum saturation.

No-till (NTS) and conventional (CTS) soil management systems with three different crop rotations and a control were implemented. The treatments consisted of rotations under no-till system (NTS) [sorghum-fallow-common bean-fallow (NTS-S), sunflower-fallow-common bean-fallow (NTS-F), maize-fallow-common bean-fallow (NTS-M)] and rotations under conventional tillage system (CTS) [sorghum-fallow-common bean-fallow (CTS-S), sunflower-fallow-common bean-fallow (CTS-F) and maize-fallow-common bean-fallow (CTS-M)]; and a control, represented by the soil of a local native forest (NF), located at $60 \mathrm{~m}$ of the experimental area. In the first year, the three species (maize, sorghum and sunflower) were cultivated in the summer-autumn intercropped with Brachiaria decumbens to increase the biomass production covering the soil, and common beans were cultivated in the winter-spring in all treatments.

The treatments were implemented in November of 2009 , with plots of $18 \times 18 \mathrm{~m} \mathrm{(324 \textrm {m } ^ { 2 } )}$ spaced $12 \mathrm{~m}$ apart to allow machine operations. The CTS consisted of disk plowing followed by a light harrowing, with incorporation of all remaining crop residues, and sowing with a pneumatic seeder, which was also used in the NTS areas. Irrigation was performed by conventional spraying, compensating the accumulated evapotranspiration, at times determined by tensiometer readings.

Historically, in the last 25 years prior to the experiment implementation, the area was cultivated with a maize-fallow-sorghum-fallow rotation, and in the last four years (2004 to 2008) the area was left fallow, with the grass Panicum maximum cv. Colonião as the predominant species. The native forest (NF) (Deciduous Forest) also known as "mata seca" was at least 40 years without human intervention.

Two years and three months after the experiment implementation, soil samples were collected in four trenches, which were considered as repetitions. Disaggregated soil samples $\left(50 \mathrm{~cm}^{2}\right)$ 
from the layers $0.00-0.05,0.05-0.10,0.10-0.20$ and $0.20-0.40 \mathrm{~m}$ were collected to evaluate the carbon content in the different fractions of the soil organic matter (SOM), total nitrogen (TN) and determination of carbon management index.

The total organic carbon (TOC) content was evaluated by the wet oxidation method, with external heating (YEOMANS; BREMNER, 1988), and the TN content by the Kjeldahl distillation (BREMNER, 1996), from which was determined the $\mathrm{C}: \mathrm{N}$ ratio.

The labile $\mathrm{C}$ (LC) content was evaluated by $\mathrm{KMnO}_{4}$ oxidation, with a solution of $0.033 \mathrm{~mol} \mathrm{~L}^{-1}$ $(25 \mathrm{~mL})$ added to $50-\mathrm{mL}$ centrifuge tubes containing $1.0 \mathrm{~g}$ of ground, sieved (0.210-mm mesh sieve) soil. The tubes were protected from light with aluminum foil, stirred at $170 \mathrm{rpm}$ for 1 hour and centrifuged at $960 \mathrm{~g}$ for $10 \mathrm{~min}$. The supernatant $(0.1 \mathrm{~mL})$ was transferred to $10-\mathrm{mL}$ test tubes, completing their volume with distilled water, and the readings were carried out in a spectrophotometer with a wavelength of $565 \mathrm{~nm}$ (SILVA et al., 2011). The non-labile C (NLC) content was estimated by the difference between the TOC and LC (NLC = TOC - LC). The chemical fractionation of humic substances (HS) was performed according to the differential solubility technique, separating the fulvic acid (FAF), humic acid (HAF) and humin (HUF) fractions (SWIFT, 1996). The water-soluble carbon (WSC) was obtained by extraction with distilled water, at soil to water ratio of $1: 2$, and determined by colorimetry (BARTLETT; ROSS, 1988).

The ratio of labile to non-labile carbon content in the SOM were used to estimate the carbon partitioning index (CPI) (CPI $=$ TOC of the cultivated soil / TOC of the native forest), lability (L) $(\mathrm{L}=\mathrm{LC} / \mathrm{NLC})$, lability index $(\mathrm{LI})(\mathrm{LI}=\mathrm{L}$ of the cultivated soil $/ \mathrm{L}$ of the native forest) and carbon management index (CMI) (CMI = CPI x LI x 100) (BLAIR; LEFROY; LISLE, 1995). The data were analyzed in a completely randomized design. The effects of land use on the SOM fractions were compared by analysis of variance and the means differentiated by the Scott-Knott test at 5\% probability. The soil layers of each treatment were individually analyzed.

\section{RESULTS AND DISCUSSION}

All soil management systems had lower total soil organic carbon (TOC) (all soil layer) and TN $(0.0-0.10 \mathrm{~m})$ contents than the soils under native forest (NF) (Table 2). The replacement of natural vegetation by crop systems changed the quality and quantity of the soil organic matter (SOM), and the high air temperature, irrigation and fertilizers accelerated the carbon oxidation. In fact, organic carbon losses are usually higher in sandy-clay-loam texture soils due to their lower specific surface, limiting the colloidal protection of the SOM, restricting their bonds with clay and sand fractions (SILVA; MENDONÇA, 2007).

The reduction in TOC and TN in the NTS was due to the NTS lower implementation time (two years and three months), since the carbon accumulation process can take 10 to 15 years to be significant (GUARESCHI; PEREIRA; PERIN, 2013). However, the amount of plant residues deposited on the soil surface by the sunflower (15.64 $\left.\mathrm{Mg} \mathrm{ha}^{-1}\right)$, sorghum (16.39 $\mathrm{Mg} \mathrm{ha}^{-1}$ ) and maize $\left(16.90 \mathrm{Mg} \mathrm{ha}^{-1}\right)$ were greater than the amounts deposited by the NF $\left(14.50 \mathrm{Mg} \mathrm{ha}^{-1}\right.$ ) (SALES et al., 2016). The NF lower biomass production is a consequence of long drought periods in the region. The plant residue deposition potential of croplands under NTS in the Brazilian semiarid region may increase with time, compared with the NF. The SOM decomposition rate reduces with time in NTS, favoring its protection within aggregates and accumulation, and ensuring a continuous flow of materials and energy through the soil, increasing the stocks of C (CAMPOS et al., 2013). The stocks of C may be low in soils under natural ecosystems that were replaced by crop systems (MARINHO et al., 2016), however, in some conditions it may be similar or higher in soils under pastures and crops under NTS (BRAZ et al., 2013).

According to the analysis of the soil management systems, the soils under NTS had higher carbon contents, especially those cultivated with maize and sorghum, compared with the soils under CTS, in the layer 0.00-0.10 m (Table 2). The soil carbon contents of the NTS-M (12.73 $\left.\mathrm{g} \mathrm{kg}^{-1}\right)$ and $\mathrm{NF}\left(12.88 \mathrm{~g} \mathrm{~kg}^{-1}\right)$ were similar in the layer $0.10-0.20 \mathrm{~m}$ (Table 2), probably because of the deep roots of the maize, which increased the $\mathrm{C}$ in this layer. The effects of soil management systems in the $\mathrm{C}$ and $\mathrm{N}$ contents reduced with depth.

The higher TOC in the soil layer $0.10-0.20 \mathrm{~m}$ under NTS, compared with the CTS, are probably related to the absence of soil disturbances and maintenance of plant residues on the soil surface, decreasing their decomposition and increasing the carbon in the surface layer (GUARESCHI; PEREIRA; PERIN, 2013). Soil disturbances and incorporation of crop residues may increase the SOM oxidation in CTS, reducing the TOC content in the soil surface layer (SÁ et al., 2014). CTS in the Brazilian semiarid region may have up to $54 \%$ less TOC than the Caatinga biome (Chromic Luvisol - SiBCS) in the soil layer $0.00-0.40 \mathrm{~m}$ (SACRAMENTO et al., 2013), and 50\% less TOC in caatinga native vegetation replaced by castor (Ricinus communis) cultivation in Oxisol (Red Latosol - SiBCS). 
Table 2. Total nitrogen (TN) and total organic carbon (TOC) contents in the layers $0.00-0.05,0.05-0.10,0.10-0.20$ and 0.20-0.40 m of an Oxisol (eutrophic Red-Yellow Latosol - SiBCS).

\begin{tabular}{|c|c|c|c|c|c|c|c|c|}
\hline $\begin{array}{c}\text { Soil } \\
\text { management } \\
\text { systems }\end{array}$ & $\mathrm{TN}$ & TOC & $\mathrm{TN}$ & TOC & $\mathrm{TN}$ & TOC & $\mathrm{TN}$ & TOC \\
\hline & & & & & $\mathrm{g}^{-1}$ & & & \\
\hline & \multicolumn{2}{|c|}{$0.00-0.05 \mathrm{~m}$} & \multicolumn{2}{|c|}{$0.05-0.10 \mathrm{~m}$} & \multicolumn{2}{|c|}{$0.10-0.20 \mathrm{~m}$} & \multicolumn{2}{|c|}{$0.20-0.40 \mathrm{~m}$} \\
\hline CTS-S & $1.03 \mathrm{~d}$ & $12.99 d$ & $0.97 b$ & $12.29 \mathrm{~d}$ & $0.80 \mathrm{a}$ & $9.97 b$ & $0.69 \mathrm{a}$ & $8.31 \mathrm{~b}$ \\
\hline CTS-F & $0.91 \mathrm{~d}$ & $13.12 \mathrm{~d}$ & $1.01 \mathrm{~b}$ & $12.27 \mathrm{~d}$ & $0.89 a$ & $10.36 b$ & $0.77 \mathrm{a}$ & $8.45 b$ \\
\hline NTS-F & $1.18 \mathrm{c}$ & $15.83 c$ & $1.08 \mathrm{~b}$ & $12.48 \mathrm{~d}$ & $0.87 \mathrm{a}$ & $10.98 b$ & $0.76 a$ & $8.05 b$ \\
\hline NTS-M & $1.50 \mathrm{~b}$ & $18.06 \mathrm{~b}$ & $1.19 \mathrm{~b}$ & $14.97 \mathrm{~b}$ & $1.03 \mathrm{a}$ & $12.73 a$ & $0.78 \mathrm{a}$ & $9.50 \mathrm{~b}$ \\
\hline NF & $1.91 \mathrm{a}$ & $25.79 a$ & $1.56 \mathrm{a}$ & $17.62 \mathrm{a}$ & $1.20 \mathrm{a}$ & $12.88 \mathrm{a}$ & $0.89 a$ & $10.72 \mathrm{a}$ \\
\hline Grand mean & 1.25 & 16.80 & 1.11 & 13.56 & 0.95 & 11.22 & 0.76 & 8.97 \\
\hline CV $(\%)$ & 9.32 & 6.81 & 11.82 & 5.78 & 19.19 & 9.64 & 14.87 & 9.04 \\
\hline
\end{tabular}

Means followed by the same letter in the column do not differ by the Scott-Knott test at 5\% probability. Soil management systems: conventional tillage system with sorghum (CTS-S), sunflower (CTS-F) and maize (CTS-M); no-till system with sorghum (NTS-S), sunflower (NTS-F) and maize (NTS-M); native forest (NF).

The soil TN in the different management systems differed only in the layer $0.00-0.05 \mathrm{~m}$. Similar to the TOC, the TN content increased in the maize $\left(1.50 \mathrm{~g} \mathrm{~kg}^{-1}\right)$ and sorghum $\left(1.32 \mathrm{~g} \mathrm{~kg}^{-1}\right)$ crops under NTS compared to the CTS $\left(0.95 \mathrm{~g} \mathrm{~kg}^{-1}\right)$ (Table 2). This result was due to the $\mathrm{N}$ and $\mathrm{C}$ structural function in the SOM, since according to Silva and Mendonça (2007), N is key for stabilization of C in the SOM. Moran et al. (2005) evaluated the effect of mineral $\mathrm{N}$ on the stabilization of the SOM in the presence of rice straw and found a higher concentration of $\mathrm{C}$ of the residue converted into humin when adding mineral ${ }^{15} \mathrm{~N}$ (163 $\mu \mathrm{g} \mathrm{g}^{-1}$ of C).

According to Sá et al. (2010), the great straw mass in the NTS contribute to reduce soil water evaporation and temperature variation, providing favorable conditions for development of tertiary roots, which have short life and high sensitivity to temperatures greater than $36^{\circ} \mathrm{C}$. These authors observed greater root growth of maize genotypes in the topsoil under the NTS that had greater amount of straw $\left(10 \mathrm{Mg} \mathrm{ha}^{-1}\right)$. Thus, the greater amounts of biomasses in the NTS-S and NTS-M, combined with their denser natural root system (ALVAREZ et al., 2014) in semiarid conditions, contributed to the greater $\mathrm{C}$ contents stored by the roots in these systems in a short time. A greater contribution of grasses for carbon stocks in the soil was also observed by Leite et al. (2013) when evaluating the soil carbon dynamic under monocultures and intercropping of macaúba palm (Acrocomia aculeata) and pasture.

The $\mathrm{C}$ content in the labile SOM fractions, i.e., labile carbon (LC) and water-soluble carbon (WSC), were greater in cultivated soils under NTS compared with those under CTS, with increases of 58.60 (maize), 68.16 (sorghum) and $74.36 \%$ (sunflower), and similar compare with the NF in the layer 0.00-0.05 m (Table 3).

Table 3. Water-soluble (WSC), labile (LC) and non-labile (NLC) carbon, fulvic acid (FAF), humic acid (HAF) and humin (HUF) fractions, humic substances (HS) and carbon to nitrogen ratio $(\mathrm{C}: \mathrm{N})$ in the layers $0.00-0.05,0.05-0.10,0.10-0.20$ and 0.20-0.40 m of an Oxisol (eutrophic Red-Yellow Latosol - SiBCS).

\begin{tabular}{|c|c|c|c|c|c|c|c|c|}
\hline \multirow[t]{3}{*}{$\begin{array}{c}\text { Soil } \\
\text { management } \\
\text { systems }\end{array}$} & WSC & $\mathrm{LC}$ & NLC & FAF & HAF & HUF & HS & $\mathrm{C}: \mathrm{N}$ \\
\hline & $\mathrm{mg} \mathrm{kg}^{-1}$ & \multicolumn{7}{|c|}{$\longrightarrow \mathrm{g} \mathrm{kg}^{-1} \longrightarrow$} \\
\hline & \multicolumn{8}{|c|}{$0.00-0.05 \mathrm{~m}$} \\
\hline CTS-S & $191.29 \mathrm{c}$ & $1.79 \mathrm{~b}$ & $11.21 \mathrm{c}$ & $1.71 \mathrm{~d}$ & $1.49 \mathrm{c}$ & $8.18 \mathrm{~d}$ & $11.38 \mathrm{~d}$ & 12.64 \\
\hline CTS-F & $187.03 \mathrm{c}$ & $1.56 \mathrm{~b}$ & $11.56 \mathrm{c}$ & $1.71 \mathrm{~d}$ & $1.62 \mathrm{c}$ & $8.41 \mathrm{~d}$ & $11.74 d$ & 14.85 \\
\hline CTS-M & $190.36 \mathrm{c}$ & $1.86 \mathrm{~b}$ & $12.14 \mathrm{c}$ & $1.68 \mathrm{~d}$ & $1.52 \mathrm{c}$ & $8.29 \mathrm{~d}$ & $11.49 \mathrm{~d}$ & 15.65 \\
\hline NTS-S & $257.45 b$ & $3.01 \mathrm{a}$ & $14.80 \mathrm{~b}$ & $2.04 \mathrm{c}$ & $2.24 b$ & $11.37 \mathrm{~b}$ & $15.65 b$ & 13.50 \\
\hline NTS-F & $255.42 b$ & $2.72 \mathrm{a}$ & $13.11 \mathrm{c}$ & $2.09 \mathrm{c}$ & $2.23 b$ & $10.33 \mathrm{c}$ & $14.64 \mathrm{c}$ & 13.48 \\
\hline NTS-M & $282.71 b$ & $2.95 \mathrm{a}$ & $15.11 \mathrm{~b}$ & $2.41 \mathrm{~b}$ & $2.42 \mathrm{~b}$ & $11.64 b$ & $16.47 \mathrm{~b}$ & 12.04 \\
\hline NF & $337.04 \mathrm{a}$ & $2.92 \mathrm{a}$ & $22.86 a$ & $2.68 \mathrm{a}$ & $3.54 \mathrm{a}$ & $17.12 \mathrm{a}$ & $23.34 \mathrm{a}$ & 13.56 \\
\hline CV (\%) & 7.99 & 16.98 & 7.96 & 7.32 & 7.80 & 5.81 & 5.43 & - \\
\hline
\end{tabular}

Means followed by the same letter in the column do not differ by the Scott-Knott test at $5 \%$ probability. Soil management systems: conventional tillage system with sorghum (CTS-S), sunflower (CTS-F) and maize (CTS-M); no-till system with sorghum (NTS-S), sunflower (NTS-F) and maize (NTS-M); native forest (NF). 
Table 3. Continuation.

\begin{tabular}{|c|c|c|c|c|c|c|c|c|}
\hline $\begin{array}{c}\text { Soil } \\
\text { management } \\
\text { systems }\end{array}$ & WSC & $\mathrm{LC}$ & NLC & FAF & HAF & HUF & HS & $\mathrm{C}: \mathrm{N}$ \\
\hline & $\mathrm{mg} \mathrm{kg}^{-1}$ & & & $\mathrm{~g} \mathrm{~kg}$ & & & & \\
\hline & & & & & $10 \mathrm{~m}$ & & & \\
\hline CTS-S & $166.07 \mathrm{~b}$ & $1.34 \mathrm{~b}$ & $10.94 \mathrm{c}$ & $1.39 \mathrm{c}$ & $1.17 \mathrm{~d}$ & $7.31 \mathrm{c}$ & $9.86 \mathrm{~d}$ & 12.72 \\
\hline CTS-F & $167.99 b$ & $1.40 \mathrm{~b}$ & $10.87 \mathrm{c}$ & $1.48 \mathrm{c}$ & $1.29 \mathrm{~d}$ & $7.28 \mathrm{c}$ & $10.04 \mathrm{~d}$ & 12.26 \\
\hline CTS-M & $173.88 b$ & $1.68 \mathrm{~b}$ & $10.55 \mathrm{c}$ & $1.32 \mathrm{c}$ & $1.34 \mathrm{~d}$ & $7.39 \mathrm{c}$ & $10.05 \mathrm{~d}$ & 12.11 \\
\hline NTS-S & $174.20 \mathrm{~b}$ & $1.45 b$ & $11.02 \mathrm{c}$ & $1.87 \mathrm{~b}$ & $1.85 \mathrm{c}$ & $7.52 \mathrm{c}$ & $11.24 \mathrm{c}$ & 14.22 \\
\hline NTS-F & $177.82 b$ & $2.09 a$ & $10.99 \mathrm{c}$ & $1.76 \mathrm{~b}$ & $1.66 \mathrm{c}$ & $7.99 \mathrm{c}$ & $11.41 \mathrm{c}$ & 11.56 \\
\hline NTS-M & $178.94 b$ & $1.85 \mathrm{~b}$ & $13.12 b$ & $1.64 \mathrm{~b}$ & $2.13 b$ & $8.88 \mathrm{~b}$ & $12.64 \mathrm{~b}$ & 12.66 \\
\hline NF & $257.00 \mathrm{a}$ & $2.63 \mathrm{a}$ & $14.98 \mathrm{a}$ & $2.39 \mathrm{a}$ & $3.12 \mathrm{a}$ & $11.20 \mathrm{a}$ & $16.71 \mathrm{a}$ & 11.49 \\
\hline \multirow[t]{2}{*}{$\mathrm{CV}(\%)$} & 17.74 & 21.29 & 7.45 & 12.11 & 10.37 & 5.37 & 3.86 & - \\
\hline & \multicolumn{8}{|c|}{$0.10-0.20 \mathrm{~m}$} \\
\hline CTS-S & $120.24 b$ & $1.05 \mathrm{~b}$ & $8.92 \mathrm{a}$ & $0.99 b$ & $0.98 b$ & $5.73 b$ & $7.70 \mathrm{c}$ & 12.51 \\
\hline CTS-F & $124.16 b$ & $1.06 \mathrm{~b}$ & $9.30 \mathrm{a}$ & $1.11 \mathrm{~b}$ & $0.93 b$ & $6.35 b$ & $8.38 \mathrm{c}$ & 11.80 \\
\hline CTS-M & $126.02 b$ & $0.88 \mathrm{~b}$ & $10.62 \mathrm{a}$ & $0.98 b$ & $1.06 \mathrm{~b}$ & $6.64 b$ & $8.68 \mathrm{c}$ & 14.40 \\
\hline NTS-S & $108.41 b$ & $0.81 \mathrm{~b}$ & $9.30 \mathrm{a}$ & $1.25 \mathrm{~b}$ & $0.88 \mathrm{~b}$ & $6.28 b$ & $8.40 \mathrm{c}$ & 10.56 \\
\hline NTS-F & $105.47 \mathrm{~b}$ & $1.13 b$ & $9.85 \mathrm{a}$ & $1.46 \mathrm{a}$ & $0.93 b$ & $6.42 b$ & $8.81 \mathrm{c}$ & 12.59 \\
\hline NTS-M & $133.34 \mathrm{~b}$ & $1.50 \mathrm{a}$ & $11.24 \mathrm{a}$ & $1.28 \mathrm{~b}$ & $1.16 \mathrm{~b}$ & $7.63 a$ & $10.07 \mathrm{~b}$ & 12.35 \\
\hline NF & $176.28 \mathrm{a}$ & $1.93 \mathrm{a}$ & $10.95 \mathrm{a}$ & $1.70 \mathrm{a}$ & $2.13 \mathrm{a}$ & $8.12 \mathrm{a}$ & $11.95 \mathrm{a}$ & 10.98 \\
\hline \multirow[t]{2}{*}{ CV (\%) } & 17.90 & 32.61 & 10.89 & 15.49 & 17.97 & 9.26 & 8.57 & - \\
\hline & \multicolumn{8}{|c|}{$0.20-0.40 \mathrm{~m}$} \\
\hline CTS-S & $51.84 \mathrm{a}$ & $0.80 \mathrm{a}$ & $7.51 \mathrm{a}$ & $0.68 \mathrm{a}$ & $0.33 b$ & $3.89 \mathrm{~b}$ & $4.89 b$ & 12.22 \\
\hline CTS-F & $56.59 \mathrm{a}$ & $0.76 \mathrm{a}$ & $7.69 \mathrm{a}$ & $0.74 \mathrm{a}$ & $0.45 b$ & $4.69 \mathrm{~b}$ & $5.89 \mathrm{~b}$ & 11.04 \\
\hline CTS-M & $55.87 \mathrm{a}$ & $0.79 a$ & $8.53 a$ & $0.71 \mathrm{a}$ & $0.37 b$ & $4.99 \mathrm{~b}$ & $6.07 \mathrm{~b}$ & 13.96 \\
\hline NTS-S & $53.58 \mathrm{a}$ & $0.84 \mathrm{a}$ & $7.64 a$ & $0.77 \mathrm{a}$ & $0.44 \mathrm{~b}$ & $4.43 b$ & $5.64 \mathrm{~b}$ & 11.84 \\
\hline NTS-F & $48.87 \mathrm{a}$ & $0.85 \mathrm{a}$ & $7.20 \mathrm{a}$ & $0.83 a$ & $0.50 \mathrm{~b}$ & $4.65 b$ & $5.98 b$ & 10.63 \\
\hline NTS-M & $50.43 a$ & $0.83 \mathrm{a}$ & $8.67 \mathrm{a}$ & $0.71 \mathrm{a}$ & $0.54 b$ & $4.99 b$ & $6.23 b$ & 12.22 \\
\hline NF & $61.15 \mathrm{a}$ & $0.95 \mathrm{a}$ & $9.77 \mathrm{a}$ & $0.95 \mathrm{a}$ & $1.33 \mathrm{a}$ & $6.15 \mathrm{a}$ & $8.43 a$ & 12.10 \\
\hline CV (\%) & 35.94 & 11.78 & 1036 & 20.35 & 56.92 & 10.22 & 9.06 & - \\
\hline
\end{tabular}

Means followed by the same letter in the column do not differ by the Scott-Knott test at $5 \%$ probability. Soil management systems: conventional tillage system with sorghum (CTS-S), sunflower (CTS-F) and maize (CTS-M); no-till system with sorghum (NTS-S), sunflower (NTS-F) and maize (NTS-M); native forest (NF).

These results were due to the straw accumulation in the NTS during all year and the maintenance of soil moisture by irrigation in the high temperatures of the Brazilian semiarid region, which favored a continuous biological activity and plant residue decomposition, increasing the SOM contents and contributing to the accumulation and maintenance of labile fractions of carbon (LOSS et al., 2013). The labile SOM fractions of the NTS was similar to the NF, denoting the system great sustainability and soil quality (SÁ et al., 2014). Schimiguel et al. (2014) evaluated the soil aggregation and labile carbon forms in NTS and CTS in crop rotations and found similar results, with the NTS increasing the labile SOM fractions to values similar to those in the NF in the soil layer 0.00-0.05 m.

The labile SOM fraction of the NTS-F was similar to the NF in the soil layer $0.05-0.10 \mathrm{~m}$, while the other crops presented no differences. The higher density of the sunflower root system promoted an
LC accumulation at this depth in the NTS, due to the slower decomposition of plant residues, which has a high C:N ratio (ORDÓÑEZ-FERNÁNDEZ et al., 2007 ), with increases of $8.21 \%$ (sorghum), $10.12 \%$ (maize) and $47.14 \%$ (sunflower) compared with the CTS.

The NTS-M had similar LC contents in the soil to the NF in the layer $0.10-0.20 \mathrm{~m}$, with greater contents than the other crops, which had similar values (Table 3 ). The LC and WSC contents of the crops were similar in the soil layer $0.20-0.40 \mathrm{~m}$, with lower values than the surface layer.

The NTS-S and NTS-M presented greater NLC contents in the soil layer $0.00-0.05 \mathrm{~m}$ than the other crops, and smaller than the NF (Table 3), denoting the greater potential of the grass in recovering carbon in less labile forms. This result was due to these crops higher TOC, which offset their lowest percentage of NLC of the TOC $(83.05 \%$ in NTS-S and $83.67 \%$ in NTS-M) compared with the other crops $(86.3 \%$ in CTS-S, $88.11 \%$ in CTS-F, 
$86.71 \%$ in CTS-M, $82.82 \%$ in NTS-F, $88.64 \%$ in NF). The NTS-M presented greater NLC contents than the other crops in the soil layer $0.05-0.10 \mathrm{~m}$, and lower only than the NF, which was also due to the greater TOC. The NLC contents of the treatments were similar in the soil layers $0.10-0.20 \mathrm{~m}$ and 0.20-0.40 m. The LC results showed higher amplitude than the NLC in all depths, except the 0.10-0.20 $\mathrm{m}$, in which the results were similar. Positive and negative differences between the treatments and the NF make the LC a more sensitive index to assess changes in SOM due to different soil management systems (SILVA et al., 2011).

The crops NTS-M, NTS-S and NTS-F showed greater $\mathrm{C}$ contents in humic substances (HS) in the soil layer $0.00-0.05 \mathrm{~m}$ than the other crops and lower only than the NF. The humic substances (HS) are the most stable forms of organic matter in the soil, representing most $(90 \%)$ of the TOC (FRACETTO et al., 2012). The HS contents in the soil layer $0.05-0.10 \mathrm{~m} \quad(\mathrm{NTS}-\mathrm{M}>\mathrm{NTS}-\mathrm{S}=\mathrm{NTS}-$ $\mathrm{F}>\mathrm{CTS}-\mathrm{M}=\mathrm{CTS}-\mathrm{F}=\mathrm{CTS}-\mathrm{S})$ are directly related to the amount of plant cover on the soil surface, and to the maintenance of soil moisture and high temperatures in the Brazilian semiarid region, which contribute to a constant biological activity, favoring the humification process (LOSS et al., 2013). According to Marinho et al. (2016) the carbon content in humic fractions are more efficient in identifying differences between soil management systems than the TOC, as well as the most labile forms of carbon.

The NTS presented greater $\mathrm{C}$ contents in the fulvic acid (FAF) and humic acid (AHF) fractions than the CTS in the soil layers 0.00-0.05 and $0.05-0.10 \mathrm{~m}$. The humin fraction (HUF) was greater in all three NTS in the layer $0.00-0.05 \mathrm{~m}$, and in the NTS-M in the layer 0.05 to $0.10 \mathrm{~m}$ (Table 3 ). The humification process and carbon accumulation increased in the HS of the topsoil under NTS, confirming the results of Guareschi, Pereira and Perin (2013), who point out the contribution of the plant residues in the soil surface (NTS) to increase the carbon content in HS

These results denote the improvement of the soil quality, since the HS contribute to generate charges in the soil, increasing the CEC and plant nutrient uptake (MARINHO et al., 2016), micronutrient mobility in the soil and soil water retention capacity (SILVA; MENDONÇA, 2007) and aggregation (SCHIMIGUEL et al., 2014). Increases in the soil $\mathrm{HS}$ also denote atmospheric $\mathrm{CO}_{2}$ reduction, mitigating the greenhouse effect (SÁ et al., 2014).

The soil under NF had greater $\mathrm{C}$ contents in HS than the soil under crops, thus, despite the positive effect of the NTS, the time of its implementation ( 2 years and 3 months) was short to achieve more stable conditions (equal to NF). According to Assis et al. (2010), the accumulation of carbon in the soil under NTS is directly related to the time of its implementation.

In the soil layer $0.10-0.20 \mathrm{~m}$, the HUF in the soil under NTS-M were similar to those in the soil under NF, and greater than the other crops (Table 3), thus confirming the NTS-M potential in recovering carbon from deep layers. The $\mathrm{C}$ content in the FAF, HAF and HUF of the soils under different management systems were similar, however, their C content in the HAF and HUF were lower than those in the soil under NF.

The NTS, in general, increased the humic fractions in soil surface layers, denoting the greater sustainability of this soil management system. This result was also observed by Campos et al. (2013), who evaluated organic carbon fractions in an Oxisol (Yellow Latosol - SiBCS) under different soil management systems.

The crop systems had CMI and sustainability indexes (LI, CPI, except L) smaller than 100, which were lower than those in the soil under NF (Table 4), denoting the negative impact of soil management systems on the stock and quality of soil organic matter (BLAIR; LEFROY; LISLE, 1995).

Table 4. Lability Index (LI), carbon partitioning index (CPI), lability (L) and carbon management index (CMI) in the layers 0.00-0.05, 0.05-0.10, 0.10-0.20 and 0.20-0.40 m of an Oxisol (eutrophic Red-Yellow Latosol - SiBCS).

\begin{tabular}{ccccc}
\hline $\begin{array}{c}\text { Soil } \\
\text { management } \\
\text { systems }\end{array}$ & LI & CPI & L & CMI \\
\hline CTS-S & $0.62 \mathrm{~b}$ & $0.50 \mathrm{~d}$ & $0.16 \mathrm{~b}$ & $31.08 \mathrm{c}$ \\
CTS-F & $0.54 \mathrm{~b}$ & $0.51 \mathrm{~d}$ & $0.14 \mathrm{~b}$ & $27.40 \mathrm{c}$ \\
CTS-M & $0.64 \mathrm{~b}$ & $0.54 \mathrm{~d}$ & $0.15 \mathrm{~b}$ & $35.91 \mathrm{c}$ \\
NTS-S & $0.94 \mathrm{a}$ & $0.61 \mathrm{c}$ & $0.21 \mathrm{a}$ & $57.70 \mathrm{~b}$ \\
NTS-F & $1.05 \mathrm{a}$ & $0.69 \mathrm{~b}$ & $0.20 \mathrm{a}$ & $73.16 \mathrm{~b}$ \\
NTS-M & $1.02 \mathrm{a}$ & $0.70 \mathrm{~b}$ & $0.20 \mathrm{a}$ & $71.53 \mathrm{~b}$ \\
\hline
\end{tabular}

Means followed by the same letter in the column do not differ by the Scott-Knott test at $5 \%$ probability. Soil management systems: conventional tillage system with sorghum (CTS-S), sunflower (CTS-F) and maize (CTS-M); no-till system with sorghum (NTS-S), sunflower (NTS-F) and maize (NTS-M); native forest (NF). 
Table 4. Continuation.

\begin{tabular}{|c|c|c|c|c|}
\hline $\begin{array}{c}\text { Soil } \\
\text { management } \\
\text { systems }\end{array}$ & LI & CPI & $\mathrm{L}$ & CMI \\
\hline $\mathrm{NF}$ & $1.00 \mathrm{a}$ & $1.00 \mathrm{a}$ & $0.13 b$ & $100.00 \mathrm{a}$ \\
\hline \multirow[t]{2}{*}{$\mathrm{CV}(\%)$} & 18.79 & 7.25 & 22.57 & 21.57 \\
\hline & \multicolumn{4}{|c|}{$0.05-0.10 \mathrm{~m}$} \\
\hline CTS-S & $0.51 \mathrm{c}$ & $0.70 \mathrm{c}$ & $0.12 \mathrm{a}$ & $35.27 \mathrm{c}$ \\
\hline CTS-F & $0.54 \mathrm{c}$ & $0.70 \mathrm{c}$ & $0.13 \mathrm{a}$ & $37.25 \mathrm{c}$ \\
\hline CTS-M & $0.56 \mathrm{c}$ & $0.71 \mathrm{c}$ & $0.13 \mathrm{a}$ & $39.62 \mathrm{c}$ \\
\hline NTS-S & $0.65 \mathrm{c}$ & $0.70 \mathrm{c}$ & $0.16 \mathrm{a}$ & $45.10 \mathrm{~b}$ \\
\hline NTS-F & $0.78 b$ & $0.75 \mathrm{c}$ & $0.19 a$ & $58.34 \mathrm{~b}$ \\
\hline NTS-M & $0.70 \mathrm{c}$ & $0.85 b$ & $0.14 \mathrm{a}$ & $60.08 b$ \\
\hline NF & $1.00 \mathrm{a}$ & $1.00 \mathrm{a}$ & $0.18 \mathrm{a}$ & $100.00 \mathrm{a}$ \\
\hline \multirow[t]{2}{*}{$\mathrm{CV}(\%)$} & 18.64 & 7.74 & 25.79 & 17.06 \\
\hline & \multicolumn{4}{|c|}{$0.10-0.20 \mathrm{~m}$} \\
\hline CTS-S & $0.63 b$ & $0.78 \mathrm{a}$ & $0.12 \mathrm{a}$ & $51.81 \mathrm{~b}$ \\
\hline CTS-F & $0.57 \mathrm{~b}$ & $0.83 \mathrm{a}$ & $0.12 \mathrm{a}$ & $46.36 \mathrm{~b}$ \\
\hline CTS-M & $0.48 b$ & $0.91 \mathrm{a}$ & $0.08 \mathrm{a}$ & $43.97 b$ \\
\hline NTS-S & $0.45 b$ & $0.81 \mathrm{a}$ & $0.08 \mathrm{a}$ & $38.52 b$ \\
\hline NTS-F & $0.62 b$ & $0.88 \mathrm{a}$ & $0.12 \mathrm{a}$ & $54.55 b$ \\
\hline NTS-M & $0.86 a$ & $1.01 \mathrm{a}$ & $0.14 \mathrm{a}$ & $90.36 \mathrm{a}$ \\
\hline $\mathrm{NF}$ & $1.00 \mathrm{a}$ & $1.00 \mathrm{a}$ & $0.18 \mathrm{a}$ & $100.00 \mathrm{a}$ \\
\hline \multirow[t]{2}{*}{ CV $(\%)$} & 30.24 & 16.93 & 36.51 & 34.43 \\
\hline & \multicolumn{4}{|c|}{$0.20-0.40 \mathrm{~m}$} \\
\hline CTS-S & $0.85 \mathrm{a}$ & $0.58 \mathrm{c}$ & $0.15 \mathrm{a}$ & $49.30 \mathrm{~d}$ \\
\hline CTS-F & $0.80 \mathrm{a}$ & $0.81 \mathrm{~b}$ & $0.10 \mathrm{a}$ & $64.78 \mathrm{c}$ \\
\hline CTS-M & $0.85 a$ & $0.97 \mathrm{a}$ & $0.08 \mathrm{a}$ & $82.59 b$ \\
\hline NTS-S & $0.88 \mathrm{a}$ & $0.86 a$ & $0.11 \mathrm{a}$ & $75.37 b$ \\
\hline NTS-F & $0.90 \mathrm{a}$ & $0.74 b$ & $0.13 \mathrm{a}$ & $66.82 \mathrm{c}$ \\
\hline NTS-M & $0.87 \mathrm{a}$ & $0.97 \mathrm{a}$ & $0.09 a$ & $84.22 b$ \\
\hline $\mathrm{NF}$ & $1.00 \mathrm{a}$ & $1.00 \mathrm{a}$ & $0.10 \mathrm{a}$ & $100.00 \mathrm{a}$ \\
\hline CV (\%) & 13.22 & 10.44 & 20.75 & 14.93 \\
\hline
\end{tabular}

Means followed by the same letter in the column do not differ by the Scott-Knott test at $5 \%$ probability. Soil management systems: conventional tillage system with sorghum (CTS-S), sunflower (CTS-F) and maize (CTS-M); no-till system with sorghum (NTS-S), sunflower (NTS-F) and maize (NTS-M); native forest (NF).

Despite the negative impact of the soil management systems, the NTS recovered the C contents and organic matter quality, thus, it is more sustainable than the CTS. The NTS promoted greater lability (L) of the organic matter, partitioning of carbon (CPI) and lability index (LI) in the layer 0.00-0.05 m, and greater carbon management index (CMI) in the topsoil (0.00-0.05 and 0.05-0.10 m) (Table 4). These positive impacts become more easily measurable with time of implementation. However, the NTS-M was the more promising crop to increase the organic carbon content in the soil, with greater straw production and CMI in the soil layer $0.10-0.20 \mathrm{~m}$, similar to the NF. Greater CMI and biomass production in NTS was also found by Conceição et al. (2014), who evaluated labile fractions and CMI of different soil management systems. On the other hand, the CTS reduced the CMI in the topsoil due to the soil disturbance, as observed by Campos et al. (2013).
These results confirm those found by Rossi et al. (2012), who evaluated the SOM dynamics in soybean crops under different straws and found higher carbon management (CMI), carbon partitioning (CPI) and lability (L) indexes in systems with greater plant cover input and without soil disturbance.

The maize promoted the highest recovery of soil carbon in the NTS in the layers $0.10-0.20$ and $0.20-0.40 \mathrm{~m}$, and in the CTS in the layer $0.20-0.40 \mathrm{~m}$ (Table 4), denoting its advantage for recovery the soil subsurface quality. Schiavo et al. (2011) assessed the carbon management index of an Oxisol (Red-Yellow Latosol - SiBCS) and found higher indexes for systems with greater vegetation cover, especially grass (Brachiaria sp.) in the layers $0.05-0.10$ and $0.10-020 \mathrm{~m}$. This greater $\mathrm{C}$ content in organic matter fractions and CMI values in the NTS denote its higher quantity and lability of the soil organic matter (CONCEIÇÃO et al., 2014), and a 
greater sustainability of this soil management system in semiarid conditions.

\section{CONCLUSIONS}

Crops under no-till system (NTS) increase the total organic carbon, total nitrogen and organic matter fractions in the soil surface layers. The rotation with grasses, especially with maize under NTS is the most promising to increase the organic carbon content in the soil subsurface layers. The NTS is more sustainable than the conventional tillage system (CTS) for the Brazilian semiarid region, since the NTS promotes higher carbon partitioning index and carbon management index, increasing the partitioning of carbon in the topsoil, reducing $\mathrm{CO}_{2}$ emissions. Irrigated NTS in the Brazilian semiarid region promotes greater carbon content in soil organic matter fractions than the CTS, with similar amounts to the native forest.

\section{ACKNOWLEDGEMENTS}

The authors thank the Coordenação de Aperfeiçoamento de Pessoal de Nível Superior (CAPES), the Coordination for the Improvement of Higher Education Personnel and Fundação de Amparo à Pesquisa do Estado de Minas Gerais (FAPEMIG), the Minas Gerais State Research Foundation by granting scholarships to the authors, and the Empresa Brasileira de Pesquisa Agropecuária (EMBRAPA), the Brazilian Agricultural Research Corporation by the support to carry out this work.

\section{REFERENCES}

ALVAREZ, C. et al. Carbon and nitrogen sequestration in soils under different management in the semi-arid Pampa (Argentina). Soil and Tillage Research, Amsterdam, v. 142, n. 1, p. 25-31, 2014.

ASSIS, C. P. et al. Organic matter and phosphorus fractions in irrigated agroecosystems in a semi-arid region of Northeastern Brazil. Agriculture, Ecosystems \& Environment, Amsterdam, v. 138, n. 1-2, p. 74-82, 2010.

BARTLETT, R. J.; ROSS, D. S. Colorimetric determination of oxidizable carbon in acid soil solutions. Soil Science Society of America Journal, Madison, v. 52, n. 4, p. 191-1192, 1988.

BLAIR, G. J.; LEFROY, R. D. B.; LISLE, L. Soil carbon fractions based on their degree of oxidation, and the development of a carbon management index for agricultural systems. Australian Journal of Agricultural Research, Clayton, v. 46, n. 7, p. 1450-1459, 1995.

BRAZ, S. P. et al. Soil Carbon Stocks under Productive and Degraded Brachiaria Pastures in the Brazilian Cerrado. Soil Science Society of America Journal, Madison, v. 77, n. 3, p. 914-928, 2013.

BREMNER, J. M. Nitrogen-Total. In: SPARKS, D. L. (Ed.). Methods of soil analysis Part 3: Chemical methods. Madison: Soil Science Society of America, 1996. n. 5, cap. 37, p. 1085-1121.

CAMPOS, L. P. et al. Estoques e frações de carbono orgânico em Latossolo Amarelo submetido a diferentes sistemas de manejo. Pesquisa Agropecuária Brasileira, Brasília, v. 48, n. 3, p. 304-312, 2013.

CONCEIÇÃO, P. C. et al. Fracionamento físico da matéria orgânica e índice de manejo de carbono de um Argissolo submetido a sistemas conservacionistas de manejo. Ciência Rural, Santa Maria, v. 44, n. 5, p. 794-800, 2014.

DONAGEMA, G. K. et al. Manual de métodos de análise de solos. 2. ed. rev. Rio de Janeiro: Embrapa Solos, 2011. 230 p. (Documentos, 132).

DORADO, J.; ALMENDROS, G.; GONZÁLEZVILA, F. J. Response of humic acid structure to soil tillage management as revealed by analytical pyrolysis. Journal of Analytical and Applied Pyrolysis, Amsterdam, v. 117, n. 1, p. 56-63, 2016.

FRACETTO, F. J. C. et al. Carbon and nitrogen stocks in soil under castor bean in the semi-arid Caatinga of Brazil. Revista Brasileira de Ciência do Solo, Viçosa, v. 36, n. 5, p. 1545-1552, 2012.

GUARESCHI, R. F.; PEREIRA, M. G.; PERIN, A. Frações da matéria orgânica em áreas de Latossolo sob diferentes sistemas de manejo no Cerrado do estado de Goiás. Semina: Ciências Agrárias, Londrina, v. 34, n. 6, p. 2615-2628, 2013.

LEITE, L. F. C. et al. Qualidade química do solo e dinâmica de carbono sob monocultivo e consórcio de macaúba e pastagem. Revista Brasileira de Engenharia Agrícola e Ambiental, Campina Grande, v. 17, n. 12, p. 1257-1263, 2013.

LOSS, A. et al. Fertilidade e carbono total e oxidável de Latossolo de Cerrado sob pastagem irrigada e de sequeiro. Ciência Rural, Santa Maria, v. 43, n. 3, p. 426-432, 2013.

MARINHO, A. C. C. S. et al. Organic matter and physicochemical attributes of a cambisol under 
different 61 agricultural uses in a semi-arid region of Brazil. Australian Journal of Crop Science, Lismore, v. 10, n. 1, p. 32-41, 2016.

MORAN, K. K. et al. Role of mineral nitrogen in residue decomposition and stable soil organic matter formation. Soil Science Society of America Journal, Madison, v. 69, n. 1, p. 1730-1736, 2005.

ORDÓÑEZ-FERNÁNDEZ, R. et al. Dynamics of residue decomposition in the field in a dryland rotation under Mediterranean climate conditions in southern Spain. Nutrient Cycling in Agroecosystems, Dordrecht, v. 79, n. 3, p. 243-253, 2007.

RESENDE, M.; FERNANDES, B.; COELHO, D. T. Levantamento de reconhecimento dos solos da Bacia de Irrigação do rio Gorutuba. Viçosa, MG: UFV, Convênio DNOCS-UREMG, 1969. 143 p. Datilografado.

ROSSI, C. Q. et al. Frações lábeis da matéria orgânica em sistema de cultivo com palha de braquiária e sorgo. Revista Ciência Agronômica, Fortaleza, v. 43, n. 1, p. 38-46, 2012.

SACRAMENTO, J. A. A. S. et al. Soil carbon and nitrogen stocks in traditional agricultural and agroforestry systems in the semiarid region of Brazil. Revista Brasileira de Ciência do Solo, Viçosa, v. 37, n. 3, p. 784-795, 2013.

SÁ, J. C. M. et al. Crescimento radicular, Extração de Nutrientes e Produção de Grãos de genótipos de milho em Diferentes quantidades de palha de aveia-preta em Plantio Direto. Revista Brasileira de Ciência do Solo, Viçosa, v. 34, n. 4, p. 1207-1216, 2010.

SÁ, J. C. M. et al. Long-term tillage systems impacts on soil $\mathrm{C}$ dynamics, soil resilience and agronomic productivity of a Brazilian Oxisol. Soil and Tillage Research, Amsterdam, v. 136, n. 1, p. 38-50, 2014.

SALES, R. P. et al. Physical quality of a Latosol under no-tillage and conventional tillage in the semi-arid region. Revista Ciência Agronômica, Fortaleza, v. 47, n. 3, p. 429-438, 2016.

SANTOS, H. G. et al. Sistema Brasileiro de Classificação de Solos. 3. ed. Brasília, DF: Embrapa. 2013. 353 p.

SCHIAVO, J. A. et al. Índice de manejo de carbono e atributos químicos de Latossolo Vermelho sob diferentes sistemas de manejo. Pesquisa Agropecuária Brasileira, Brasília, v. 46, n. 10, p. 1332-1338, 2011.
SCHIMIGUEL, R. et al. Estabilidade de agregados do solo devido a sistemas de cultivo. Synergismus scyentifica, Pato Branco, v. 9, n. 1, p. 1-5, 2014.

SILVA, E. F. DA et al. Labile and recalcitrant fractions of soil organic matter under integrated crop-livestock system. Pesquisa Agropecuária Brasileira, Brasília, v. 46, n. 10, p. 1321-1331, 2011

SILVA, I. R.; MENDONÇA, E. S. Matéria orgânica do solo. In: NOVAIS, R. F. et al. (Eds.). Fertilidade do solo. Viçosa, MG: Sociedade Brasileira de Ciência do Solo, 2007. cap. IV, p. 275-374.

SWIFT, R. S. Organic matter characterization. In: SPARKS, D. L. et al. (Eds.). Methods of soil analysis: Part 3. Chemical methods. Madison: Soil Science Society of America, 1996. p. 1011-1069.

YEOMANS, J. C.; BREMNER, J. M. A rapid and precise method for routine determination of organic carbon in soil. Communications in Soil Science and Plant Analysis, New York, v. 19, n. 13, p. $1467-1476,1988$. 